\title{
Sistem Informasi Inventory Obat Pada Apotek Tritunggal Farma Jakarta
}

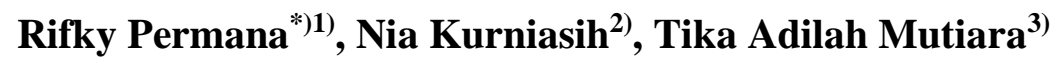 \\ ${ }^{1)}$ Program Studi Sistem Informasi, Universitas Bina Sarana Informatika \\ ${ }^{2}$ Program Studi Sistem Informasi, STMIK Nusa Mandiri \\ ${ }^{3)}$ Program Studi Teknik Informatika, Universitas Bina Sarana Informatika \\ ${ }^{*}$ Correspondence author: rifky.rpp@ bsi.ac.id, DKI Jakarta, Indonesia
}

\begin{abstract}
Abstrak
Dalam era globalisasi sekarang ini, teknologi informasi melaju dengan cepatnya. Komputer merupakan peralatan yang diciptakan untuk mempermudah suatu pekerjaan, baik di dalam pembuatan hardware maupun software. Apotek Tritunggal Farma membutuhkan adanya suatu sistem informasi yang akurat untuk menunjang kegiatan perusahaan. Untuk itu penulis mencoba membuat penelitian mengenai perancangan sistem persediaan obat pada Apotek Tritunggal Farma yang sampai saat ini belum terkomputerisasi. Sistem yang ada pada Apotek Tritunggal Farma ini masih dilakukan secara manual, mulai dari pencatatan order obat, penerimaan obat, pengeluaran obat sampai penyimpanan data-data lainnya yang berhubungan dengan proses persediaan obat sampai dengan pembuatan laporan, pencatatan data, juga kurangnya tingkat keakuratan laporan yang dibuat dan keterlambatan dalam pencarian data-data yang diperlukan. Komputerisasi sistem merupakan solusi yang terbaik untuk memecahkan permasalahan-permasalahan yang ada pada apotik ini, dengan sistem yang sudah terkomputerisasi dapat tercapai suatu pekerjaan yang efektif dan efisien dalam menunjang aktifitas persediaan barang pada apotik ini. Maka dari itu dengan sistem yang terkomputerisasi lebih baik dari sistem yang manual dengan tujuan supaya berjalan lebih efektif dan efisien dan sistem penjualan yang sekarang lebih sistematis dan praktis dibandingkan dengan sistem yang terdahulu.
\end{abstract}

Kata Kunci: Sistem Informasi, Inventory, Persediaan Obat

\begin{abstract}
In the current era of globalization, information technology is advancing rapidly. A computer is equipment that was created to facilitate work, both in making hardware and software. Tritunggal Farma Pharmacy requires an accurate information system to support company activities. Tritunggal Farma which until now has not been computerized. The existing system at the Pharmacy is still done manually, starting from recording drug orders, receiving drugs, opening drugs to store other data relating to the process of making drugs to making reports, recording data, as well as evaluating the accuracy of reports made and postponed the search for data needed. Computerized system is the best solution to solve the problems that exist in this pharmacy, with a computerized system that can achieve an effective and efficient job in supporting the activities of providing goods at this pharmacy. Therefore a computerized system is better than a manual system with the aim of being easier and more efficient and a sales system that is now more systematic and practical than an older system.
\end{abstract}

Keywords: Information Systems, Inventory, Medicine Supply

\section{PENDAHULUAN}

Teknologi informasi terus berkembang pesat seiring dengan kemampuan komputer dalam memberi solusi bagi permasalahan diberbagai bidang. Salah satu perkembangan teknologi informasi yaitu adanya sistem informasi yang bisa memberikan solusi untuk proses pengolahan data obat pada apotek. Apotek adalah suatu tempat dimana dilakukan pekerjaan kefarmasian dan penyaluran obat kepada masyarakat. Apotek sangat berperan 
penting bagi kesehatan masyarakat umum, sehingga dalam pelayanan kepada masyarakat harus bisa semaksimal mungkin.

Apotek Tritunggal Farma merupakan salah satu dari badan usaha CV. Bayu Prima Sukses yang bergerak dibidang kesehatan, dimana pada apotek ini masih menggunakan proses yang manual. Salah satunya dalam menyajikan laporan persediaan barang yang pembukuannya masih menggunakan sebuah buku yang dinilai kurang efisien. Serta memungkinkan adanya penimbunan barang yang berlebihan atau tidak diketahuinya stok barang yang sudah habis digudang.

Menurut Astuti (2013:13) Apotek merupakan salah satu jenis usaha dibidang perobatan yang sangat memerlukan adanya sistem informasi pengolahan data untuk mempermudah dan memperlancar kinerjanya. Sekarang ini, masih banyak penulisan/pencatatan data-data (obat) pada apotek yang dilakukan secara konvensional. Cukup banyak apotek yang masih memberdayakan tenaga manusia untuk mengolah data-data yang ada demi memperlancar usahanya. Sistem yang masih digunakan adalah sistem konvensional yaitu pencatatan, baik itu transaksi penjualan maupun pembelian barang ke dalam sebuah buku. Karena sistem tersebut, membuat kinerja apotek menjadi kurang efektif dan efisien.

Adapun tinjauan jurnal terkait sebelumnya yang digunakan dalam penulisan ini adalah sebagai berikut:

Mujiati dkk (2013:1) Dalam melakukan aktifitas persediaan obat pada Apotek Arjowinangun memerlukan keakuratan data demi kelancaran proses transaksi. Oleh karena itu, perlu suatu sistem yang dapat membantu Apotek dalam melakukan perencanaan strategis dalam pengambilan suatu keputusan secara efektif. Karena permasalahan tersebut maka perlu suatu sistem informasi persediaan obat pada Apotek Arjowinangun.

Rusdah (2011:51) Sistem manual pada Puskesmas Kecamatan Kebon Jeruk yang berjalan saat ini tentu tidak dapat berjalan dengan maksimal dikarenakan adanya kesalahankesalahan yang mungkin dilakukan seperti pencatatan data obat yang salah atau kurang teliti sehingga mengakibatkan persediaan obat menjadi kosong atau berlebih, dan menumpuknya obat kadaluarsa. Untuk menghindari kemungkinan timbulnya kesalahankesalahan tersebut maka dibutuhkan suatu sistem terkomputerisasi guna menyediakan informasi yang lebih cepat, tepat dan akurat kepada pihak gudang dan unit / Puskesmas Kelurahan.

Astuti (2013:14) Pada apotek banyak data-data obat, data transaksi, dan lain-lain yang tidak mungkin dihafalkan. Oleh sebab itu, dibutuhkan sebuah catatan yang dapat mendata 
daftar transaksi dan data obat. Perbaikan yang akan dilakukan yaitu membuat sistem pencatatan dengan menggunakan sistem yang berbasis komputer, baik dari segi pendataan barang persediaan, pencatatan data transaksi, dan proses yang lainnya yang berhubungan dengan aktivitas pada apotek yang bersangkutan.

Dari ketiga jurnal tersebut dapat disimpulkan perlunya dibuat sistem persediaan obat yang terkomputerisasi untuk mengurangi terjadinya kesalahan dalam penginputan data keluar masuknya obat pada apotek dan untuk menyediakan informasi yang lebih akurat tentang stok barang yang tersedia.

Menurut Alter dalam Mulyanto (2009:28) menyimpulkan bahwa "Sistem informasi sebagai kombinasi antar prosedur kerja, informasi, orang, dan teknologi informasi yang diorganisasikan untuk mencapai tujuan dalam sebuah organisasi.

Menurut Madcoms (2011:2) "Inventory merupakan proses mengelola pengadaan atau persediaan barang digudang. Inventory adalah salah satu aktiva lancar perusahaan yang pada dasarnya adalah sistem pengolahan barang yang meliputi pembelian, penjualan dan kontrol stok barang".

Menurut Rosa dan Shalahuddin (2011:113) “ UML (Unified Modelling Languange) adalah salah satu standar bahasa yang banyak digunakan di dunia industri untuk mendefinisikan kebutuhan, membuat analisis dan desain serta menggambarkan arsitektur dalam pemrograman berorientasi objek."

Menurut Widodo dan Herlawati (2011:6) "Unified Modelling Language (UML) adalah bahasa pemodelan standar." Menurut Chonoles dalam Widodo dan Herlawati (2011:6) mengatakan sebagai bahasa UML memiliki sintaks dan semantik. Menurut Widodo dan Herlawati (2011:21) Mengartikan use case sebagai urutan langkah-langkah yang secara tindakan saling terkait (skenario), baik terotomatisasi maupun secara manual, untuk tujuan melengkapi satu tugas bisnis tunggal. Use case digambarkan dalam bentuk ellips/oval. Use case sangat menentukan karakteristik sistem yang kita buat. Menurut Rosa dan Shalahuddin (2011:13) “ Yang dimaksud dengan use case adalah pemodelan untuk kelakuan (behavior) sistem informasi yang akan dibuat".

Menurut Widodo dan Herlawati (2011:11) “ Activity Diagram adalah tipe khusus dari diagram status yang memperlihatkan aliran dari suatu aktivitas ke aktivitas lainnya dalam suatu sistem”. Menurut Rosa dan Shalahuddin (2011:134) “Diagram aktivitas atau activity diagram menggambarkan workflow (aliran kerja) atau aktivitas dari sebuah sistem atau proses bisnis". Menurut Widodo dan Herlawati (2011:12) Diagram deployment 
memperlihatkan konfigurasi saat aplikasi dijalankan (run-time). Memuat simpul-simpul beserta komponen-komponen yang ada di dalamnya. Diagram deployment berhubungan erat dengan diagram komponen dimana diagram ini memuat satu atau lebih komponenkomponen. Diagram ini sangat berguna saat aplikasi kita berlaku sebagai aplikasi yang dijalankan pada banyak mesin (distributed computing). Menurut Rosa dan Shalahuddin (2011:149) “ Diagram deployment atau deployment diagram menunjukan konfigurasi komponen dalam proses eksekusi aplikasi”. Menurut Rosa dan Shalahuddin (2011:125) “ Diagram komponen atau component diagram dibuat untuk menunjukan organisasi dan ketergantungan diantara kumpulan komponen dalam sebuah sistem".

Menurut Ladjamudin (2013:70) menyatakan bahwa "Entity Relation Diagram (ERD) adalah suatu model jaringan yang menggunakan susunan data yang disimpan dalam sistem secara abstrak."

\section{METODE}

Identifikasi masalah pada penelitian ini :

1. Bagaimana menyajikan laporan persediaan barang yang cepat dan akurat sehingga dapat mencegah terjadinya penimbunan barang yang berlebihan di gudang maupun barang yang sudah habis tidak diorder kembali

2. Menyediakan kemudahan bagi pegawai Apotek untuk memeriksa dan mengecek barang yang kurang atau sudah habis stoknya

3. Membuat aplikasi untuk dapat membantu penyajian informasi tentang persediaan barang Apotek.

Pembahasan pada penelitian ini meliputi prosedur penginputan data obat, data supplier, data user, transaksi order obat, transaksi penerimaan obat, transaksi pengeluaran obat sampai dengan laporan data obat, laporan data supplier, laporan order obat, laporan penerimaan obat dan laporan pengeluaran obat juga dilengkapi dengan menu ganti password dan backup data.

Bagian gudang menerima laporan dari bagian penjualan akan adanya kekosongan stok obat berdasarkan buku defekta atau buku stok barang. Setelah mengecek dan menyesuaikan dengan buku defekta, maka bagian gudang mengajukan permintaan pengiriman barang ke bagian pengadaan barang. Setelah itu bagian pengadaan akan membuat PO untuk masingmasing distributor berdasarkan item dan jumlah permintaan dengan mempertimbangkan stok yang ada. Berdasarkan PO tersebut maka supplier akan mengirim barang ke bagian pengadaan berdasarkan item, jumlah, harga, kondisi barang dan expired. 
Program inventory obat pada Apotek Tritunggal Farma lebih efisien dengan menggunakan beberapa user. Berikut ini spesifikasi kebutuhan (system requirement) dari program inventory tersebut.

Akses Pemilik :

A1.Pemilik dapat melakukan Login

A2.Pemilik dapat mengolah data user

A3.Pemilik dapat melihat laporan : obat, supplier, transaksi order, transaksi penerimaan dan transaksi pengeluaran

A4.Pemilik dapat Logout

Akses Admin :

B1.Admin dapat melakukan Login

B2.Admin dapat mengolah data obat

B3.Admin dapat mengolah data supplier

B4.Admin dapat mengolah data transaksi order

B5.Admin dapat mengolah data transaksi penerimaan

B6.Admin dapat mengolah data transaksi pengeluaran

B7.Admin dapat cetak laporan : obat, supplier, transaksi order, transaksi penerimaan dan transaksi pengeluaran

B8.Admin dapat mengolah data BackUp

B9.Admin dapat Logout

Akses Kasir:

C1.Kasir dapat Login

C2.Kasir dapat mengolah data transaksi order

C3.Kasir dapat mengolah data transaksi penerimaan

C4.Kasir dapat mengolah data transaksi pengeluaran

C5.Kasir dapat cetak laporan : transaksi order, transaksi penerimaan dan transaksi pengeluaran

C6.Kasir dapat Logout 


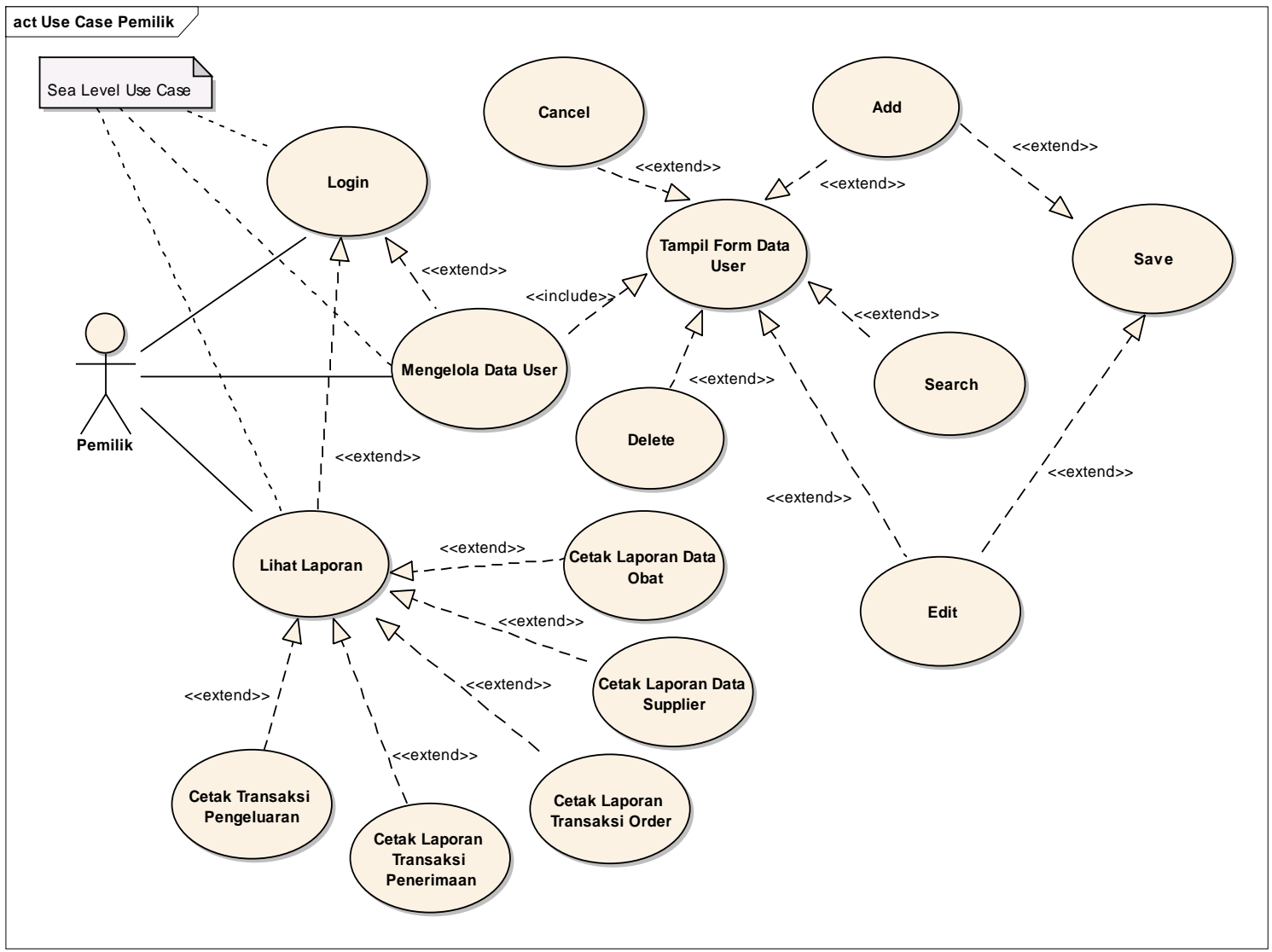

Gambar 1.

Use Case Diagram Inventory Akses Pemilik

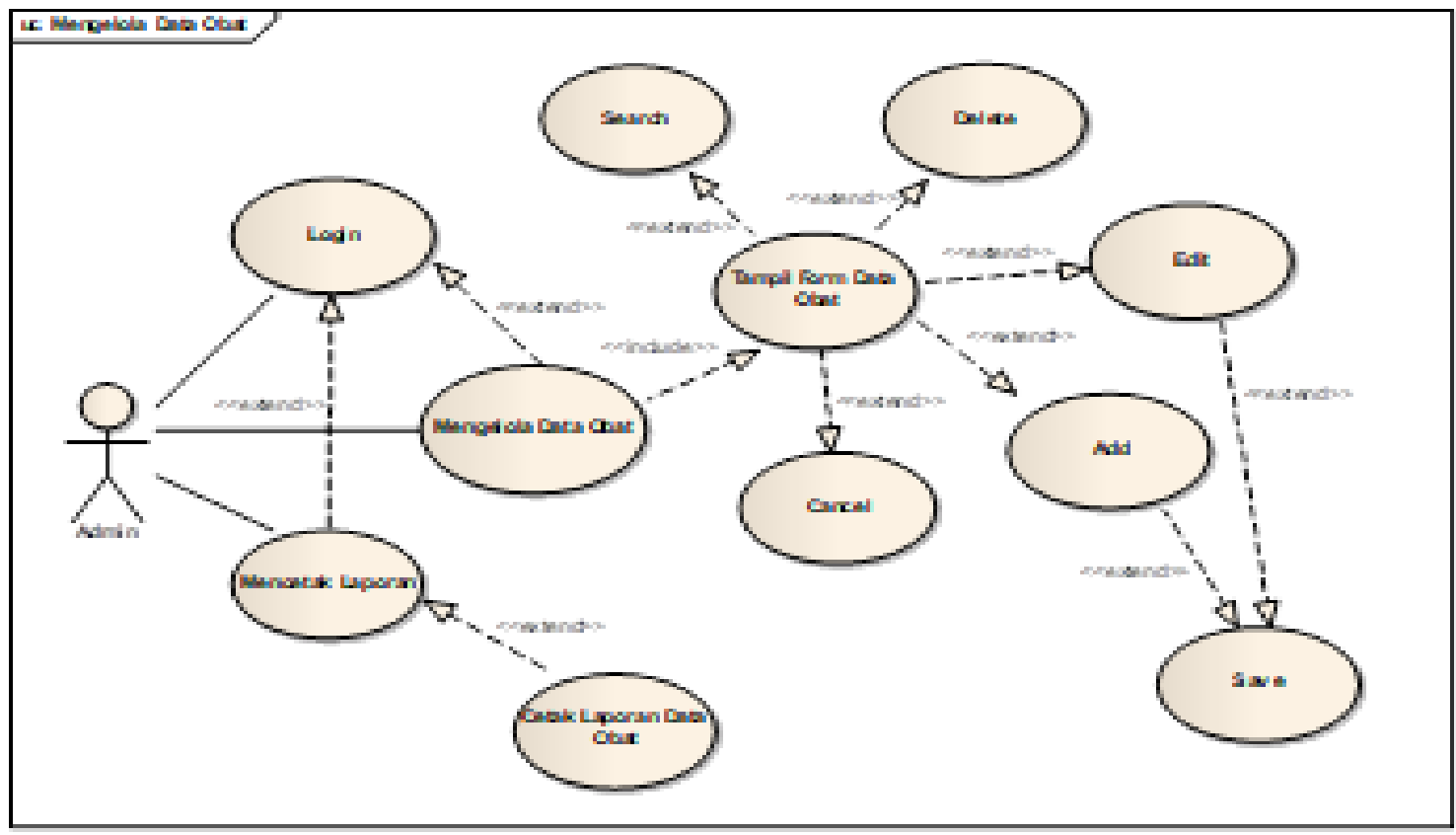

Gambar 2.

Detail Use Case Diagram Inventory Mengelola Data Obat 


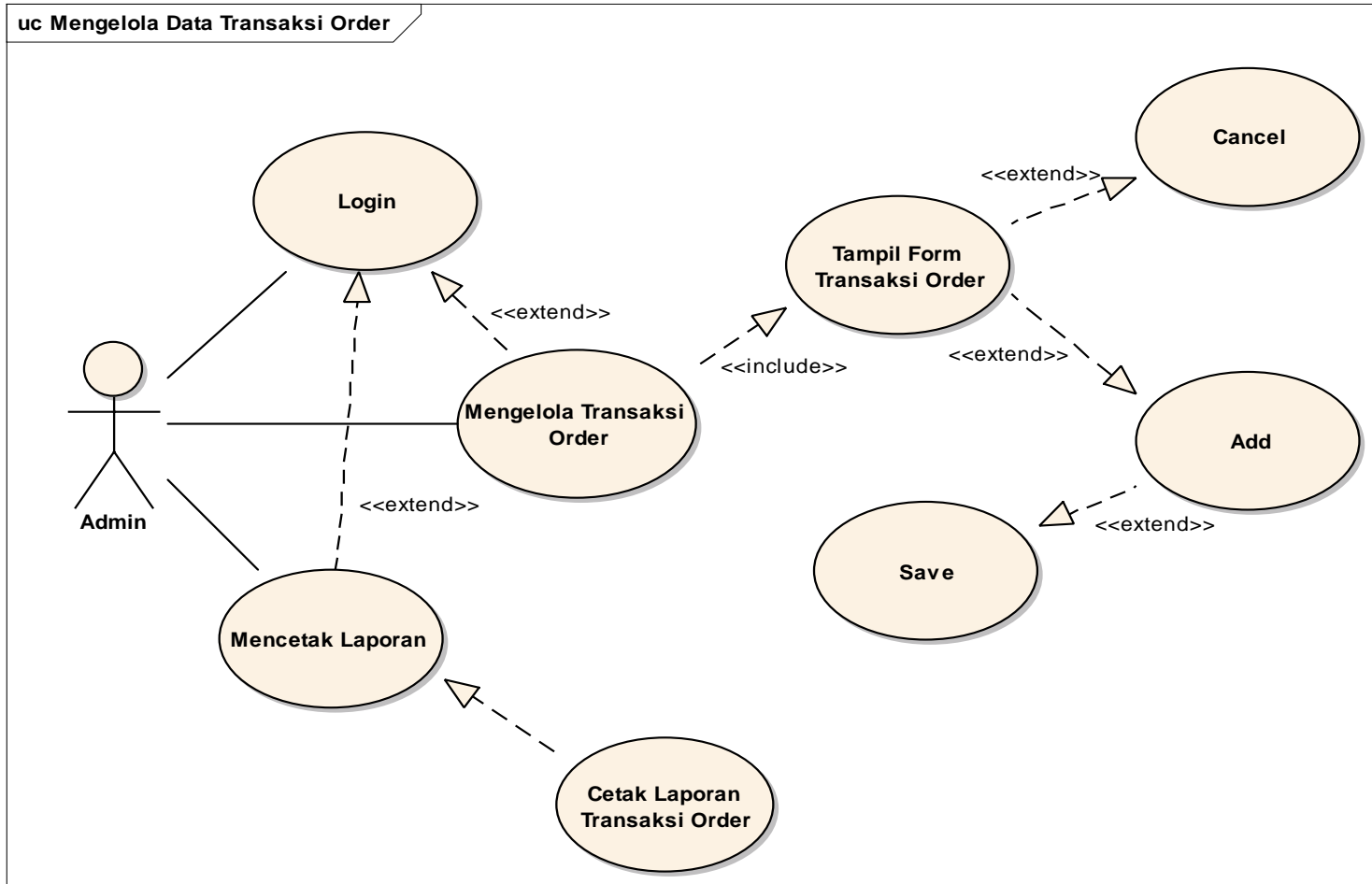

Gambar 3.

Detail Use Case Diagram Inventory Mengelola Transaksi Order

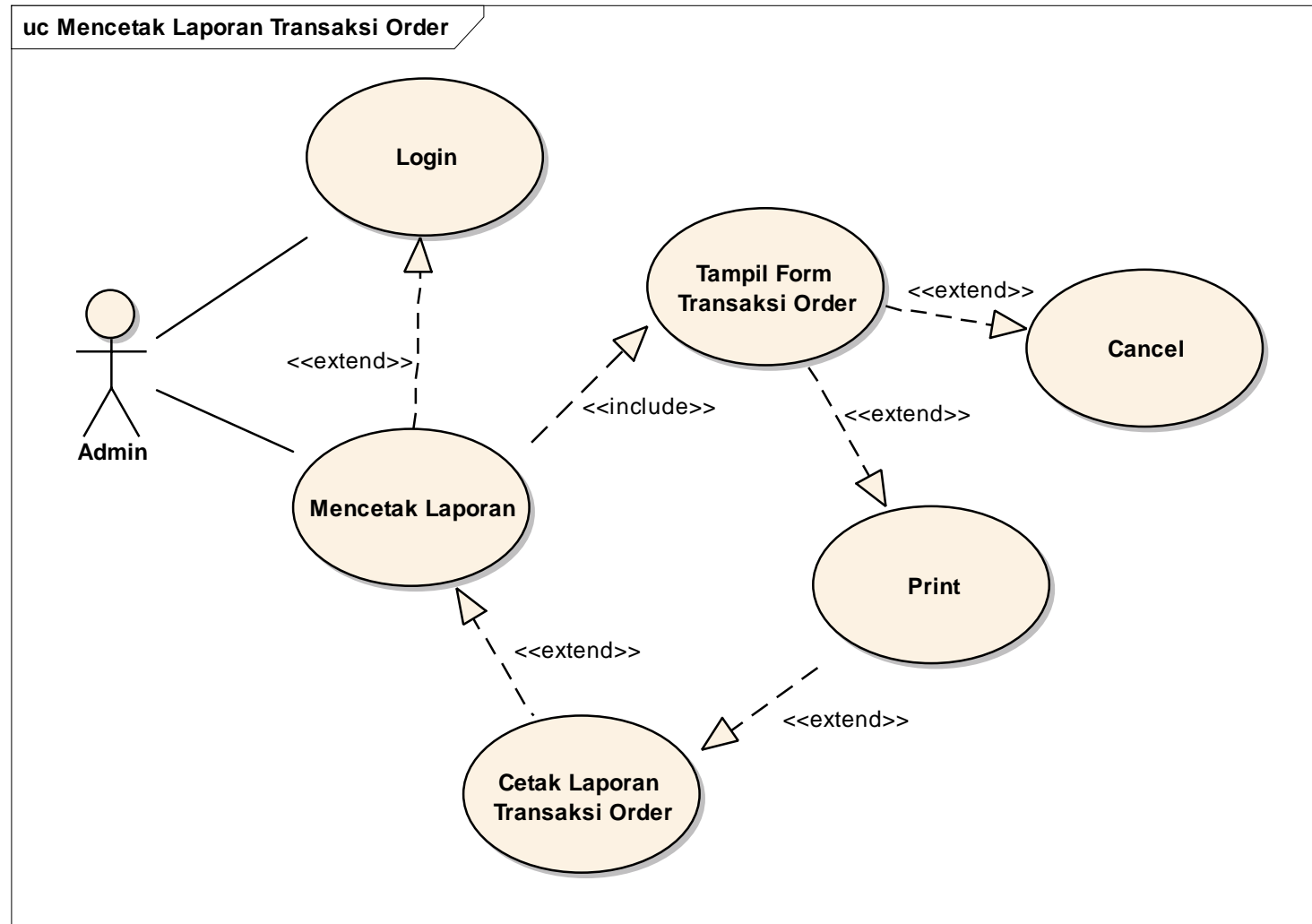

Gambar 4.

Detail Use Case Diagram Inventory Mencetak Laporan Transaksi Order 


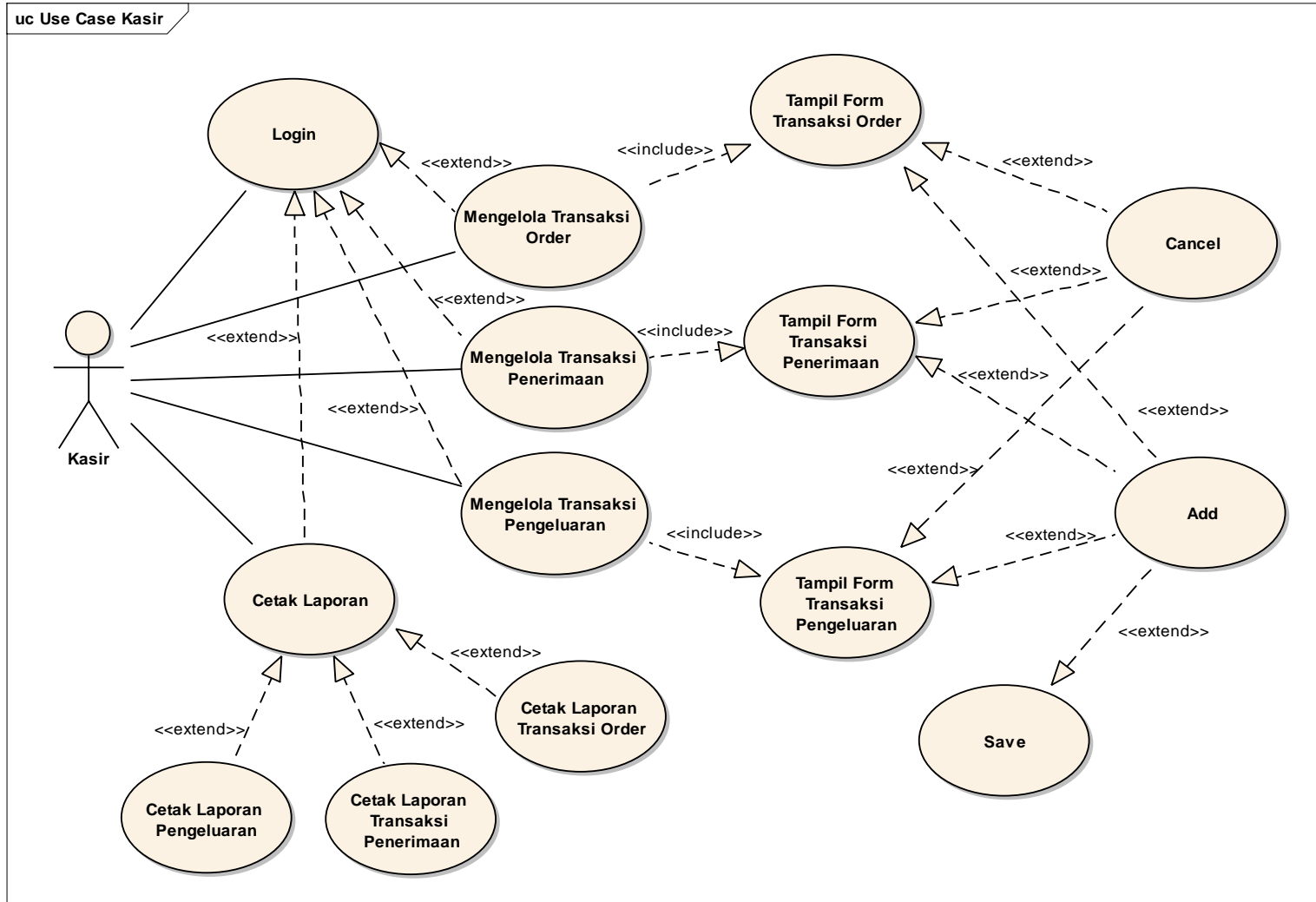

Gambar 5.

Use Case Diagram Inventory Akses Kasir

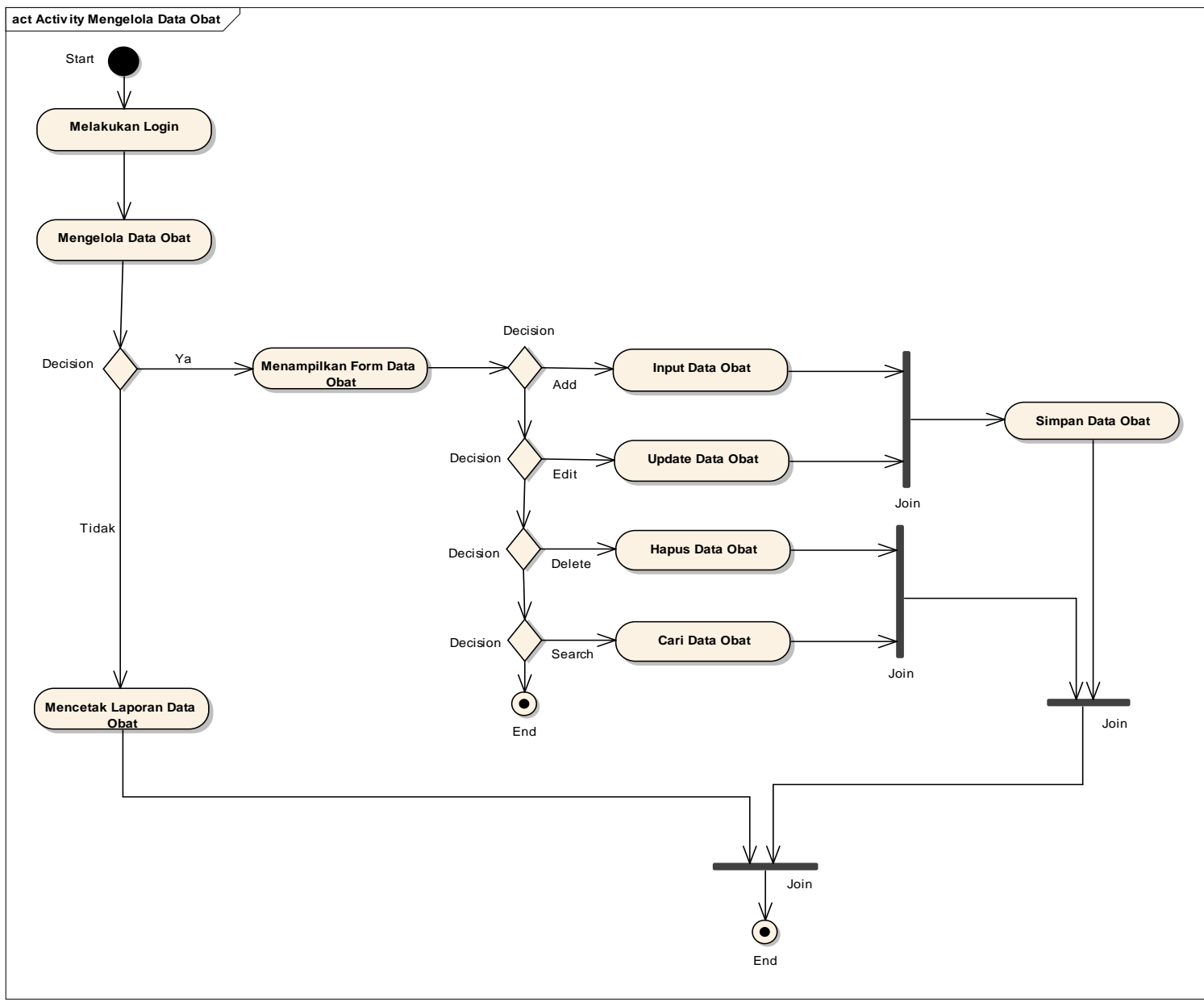

Gambar 6.

Activity Diagram Mengelola Data Obat 


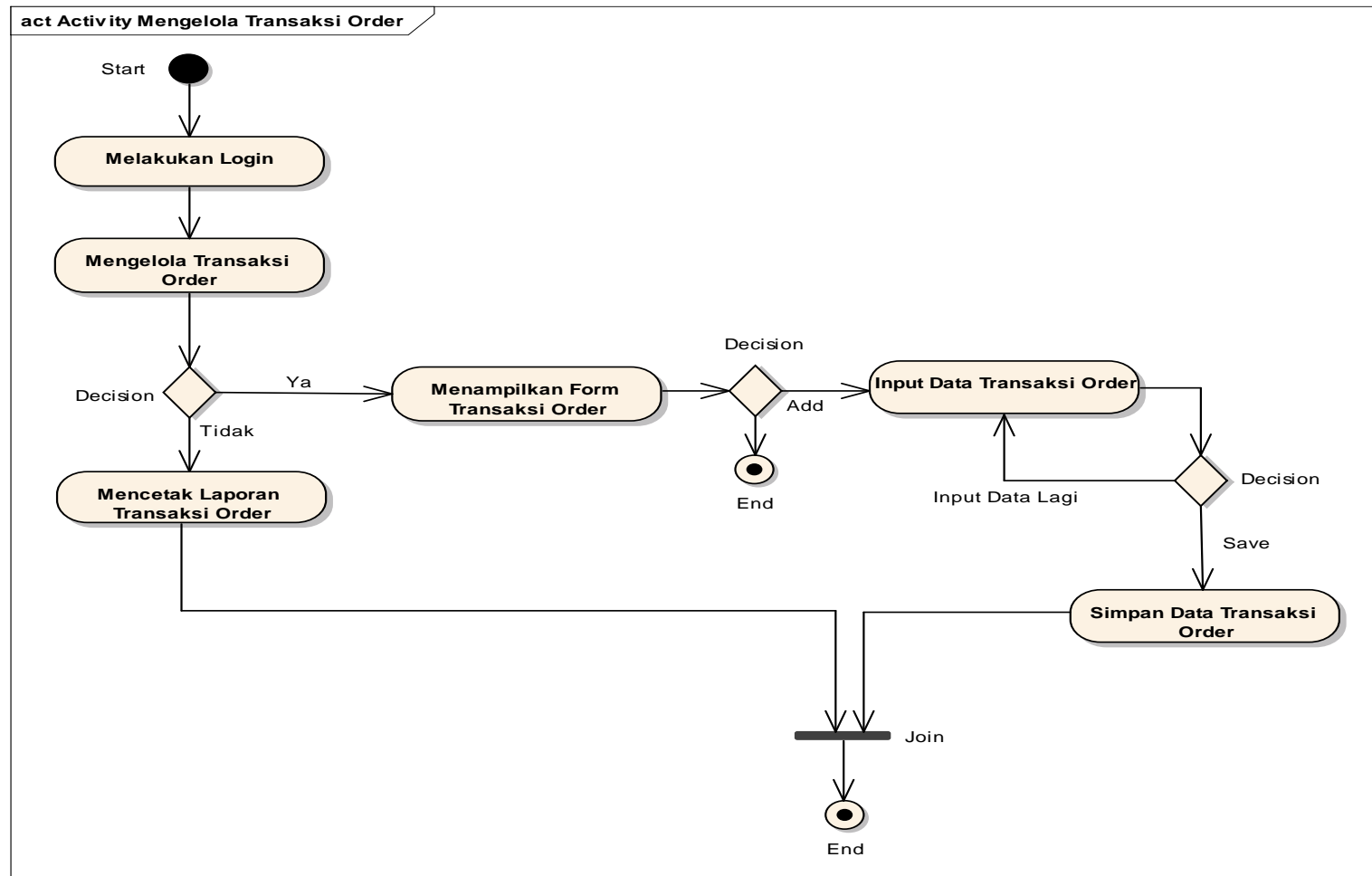

Gambar 7.

Activity Diagram Mengelola Transaksi Order

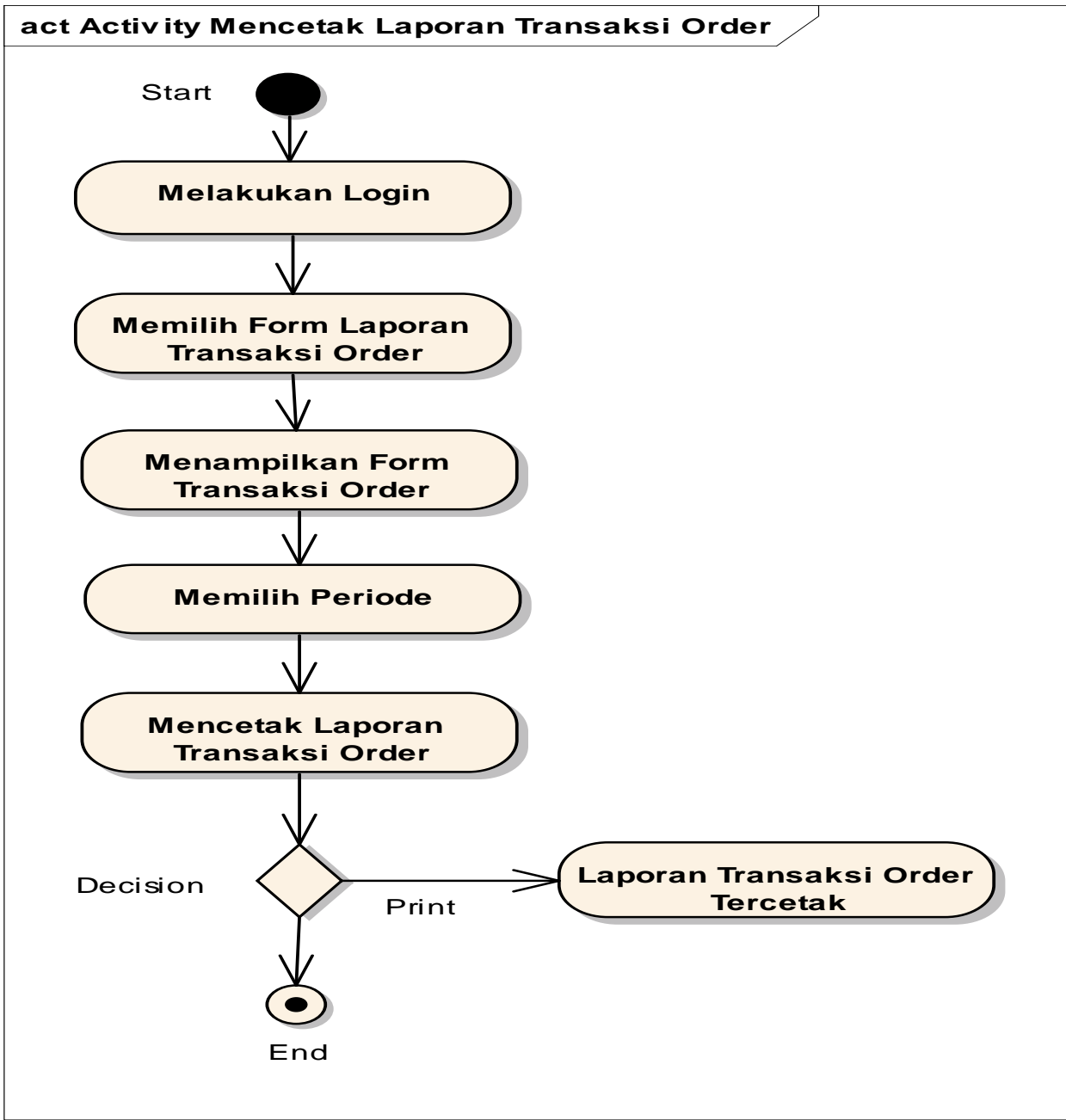

Gambar 8.

Activity Diagram Mencetak Laporan Transaksi Order 


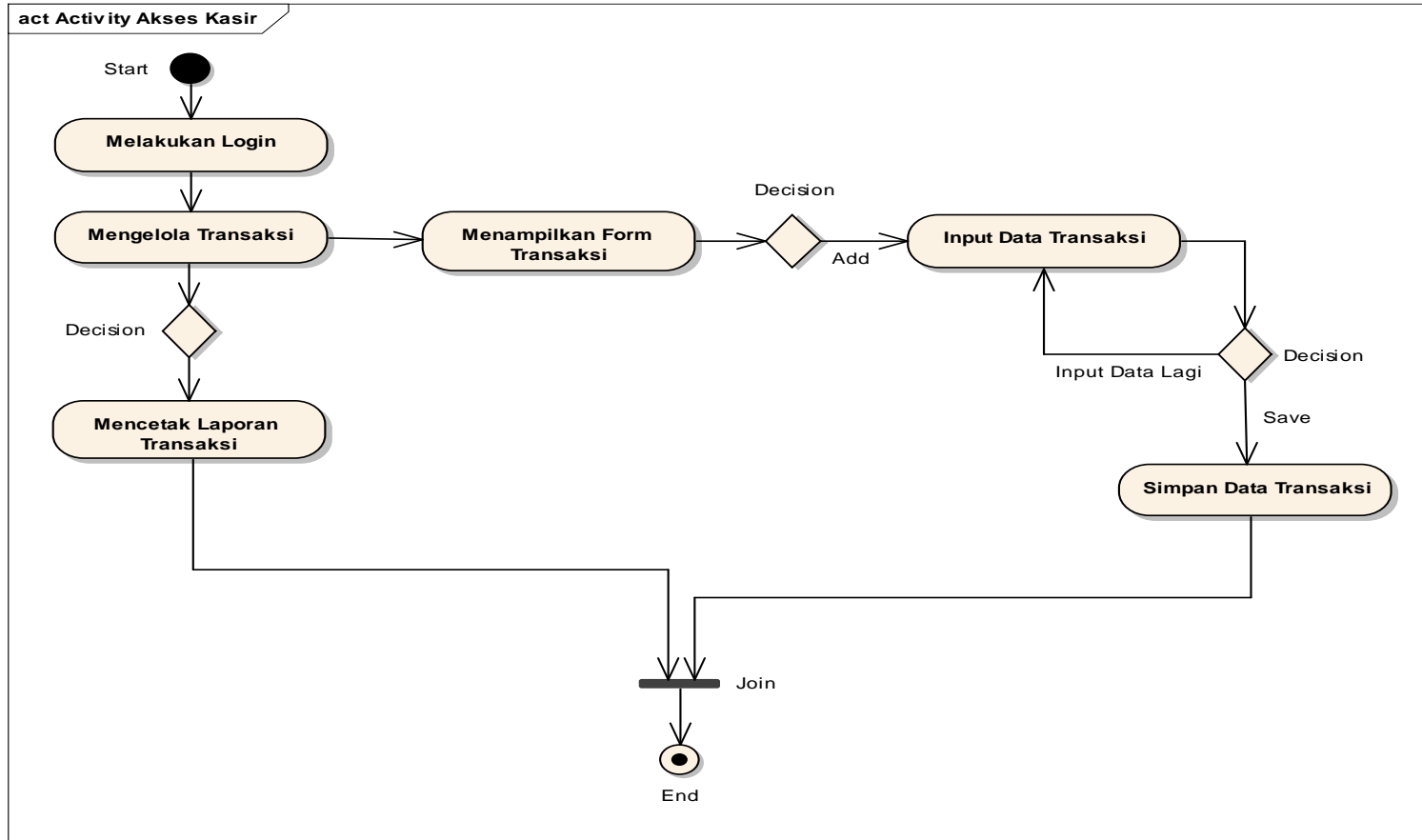

Gambar 9.

Activity Diagram Akses Kasir

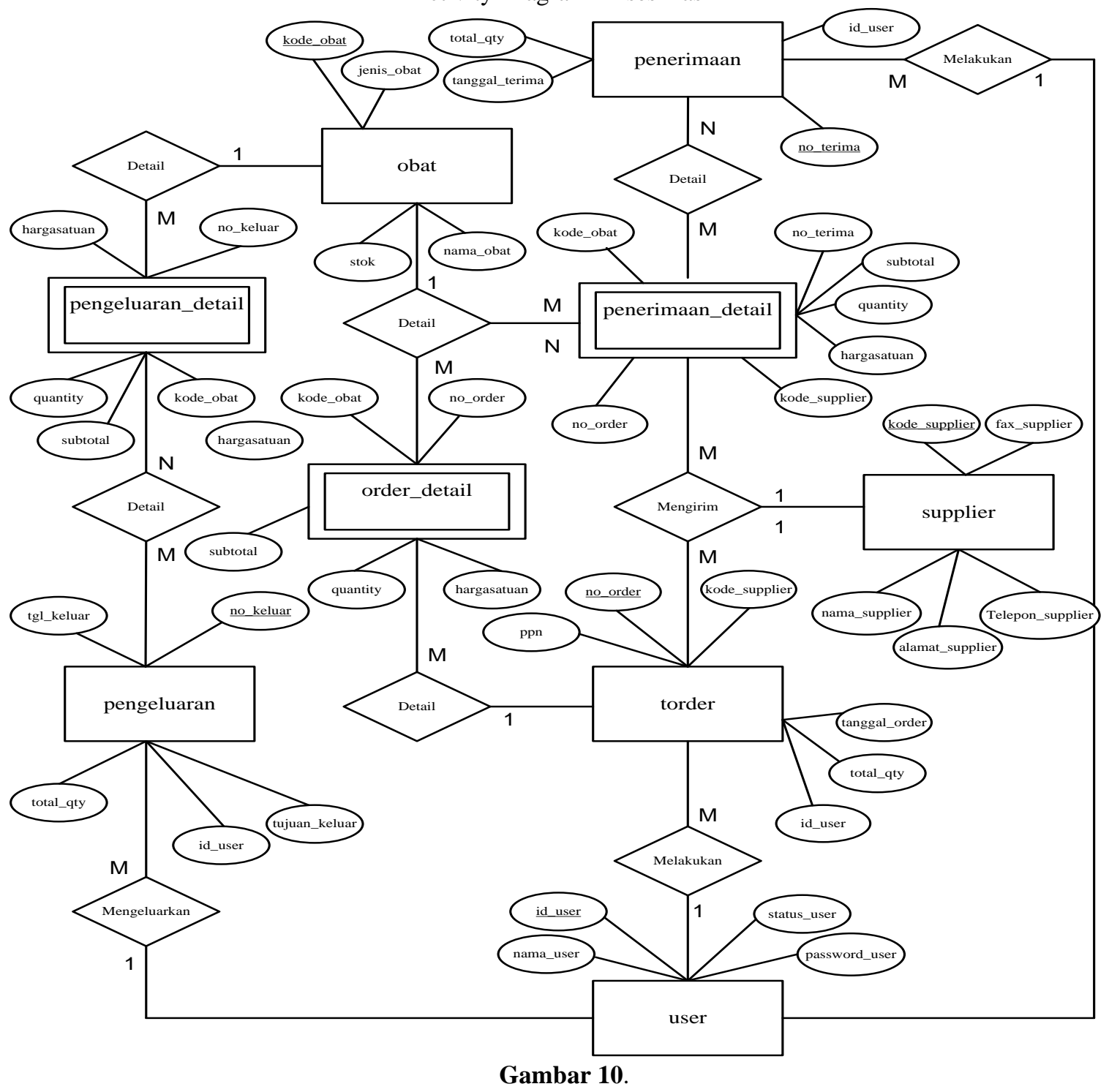

ERD (Entity Relationship Diagram) 


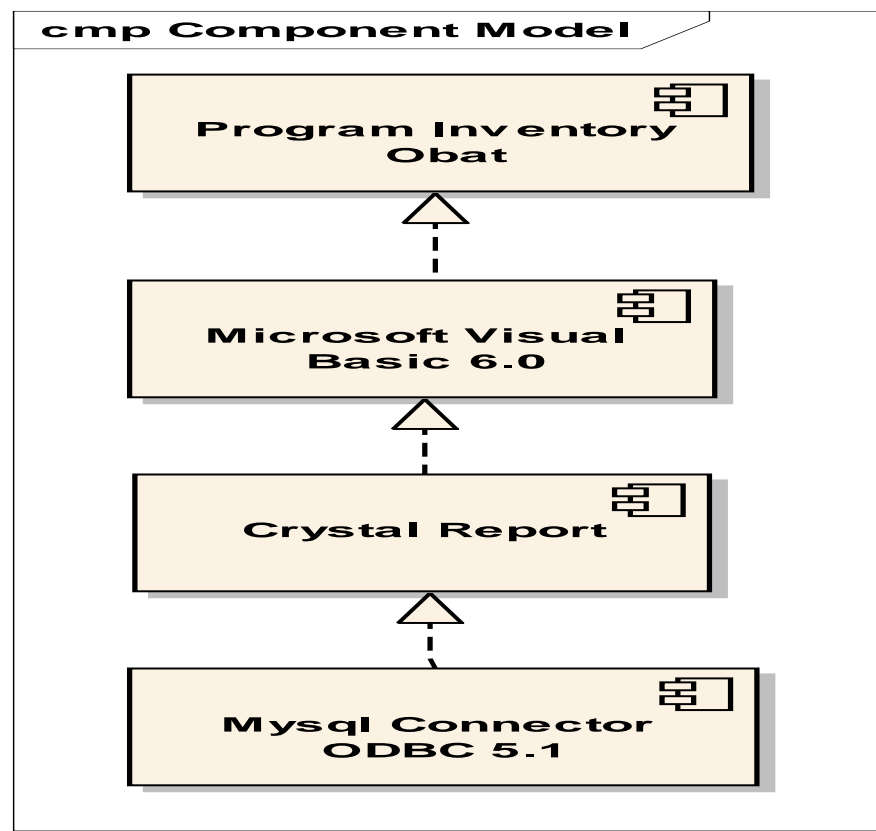

Gambar 11.

Component Diagram

\section{HASIL DAN PEMBAHASAN}

Berikut ini ditampilkan hasil dari pembuatan program, meliputi antar muka, form input, dan keluaran program.

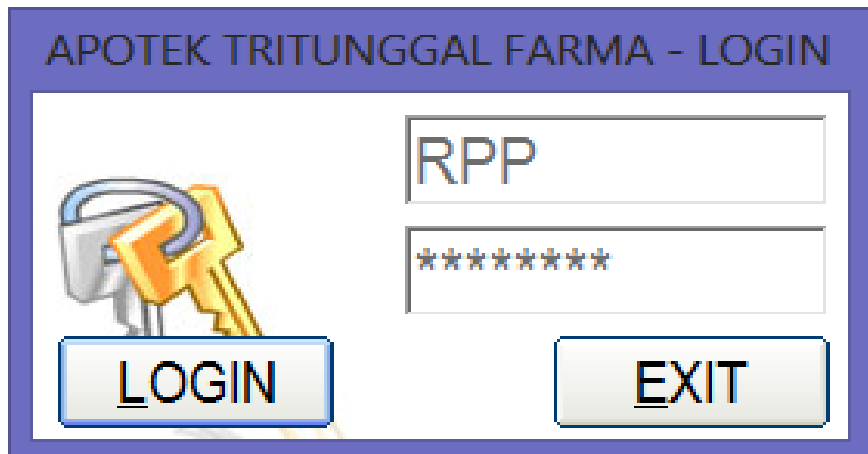

Gambar 12.

Tampilan Login

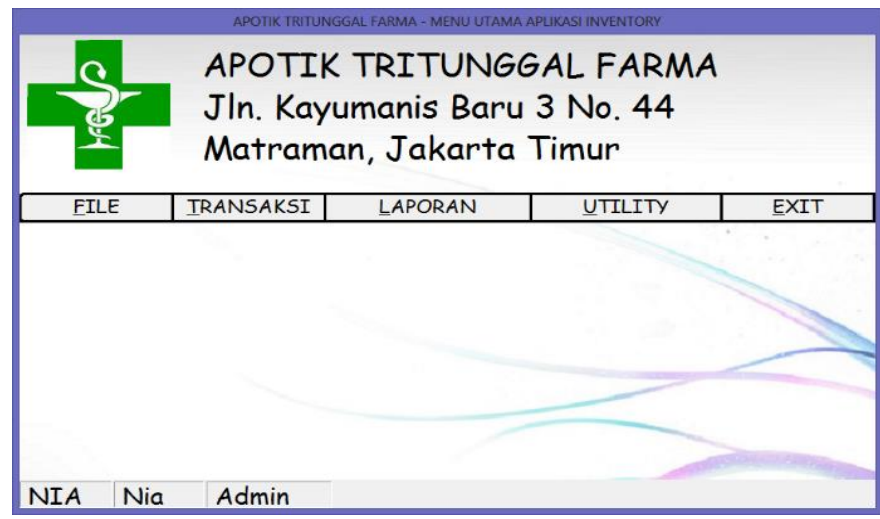

Gambar 13.

Tampilan Menu Utama 


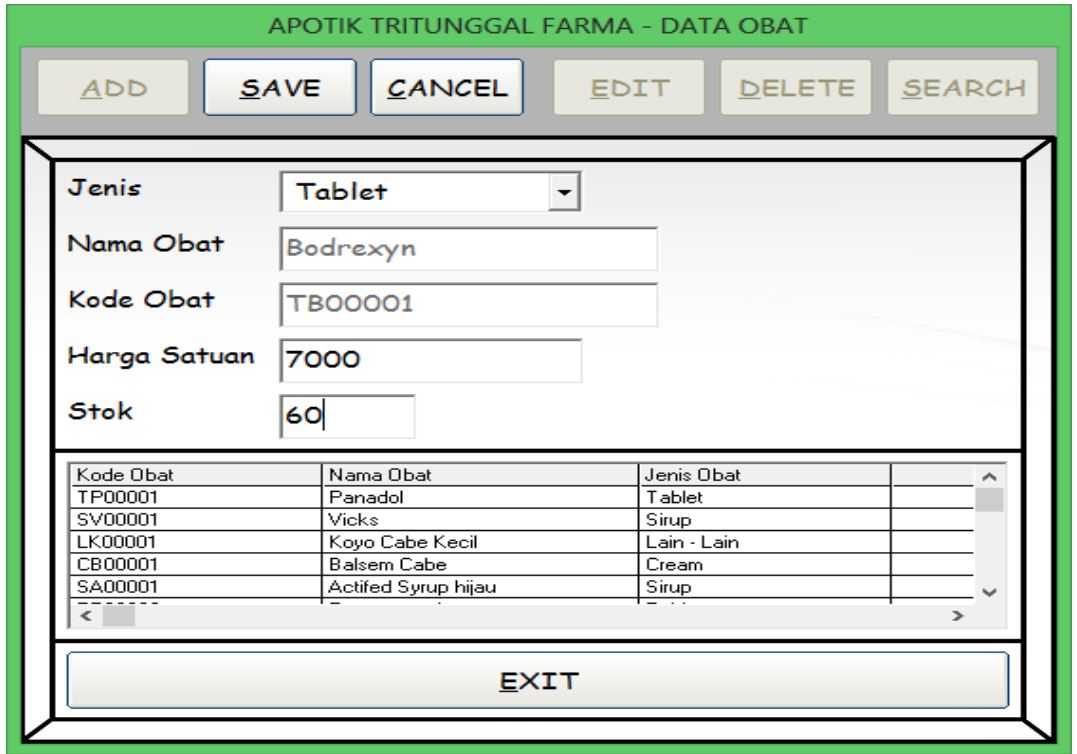

Gambar 14.

Tampilan Form Data Obat

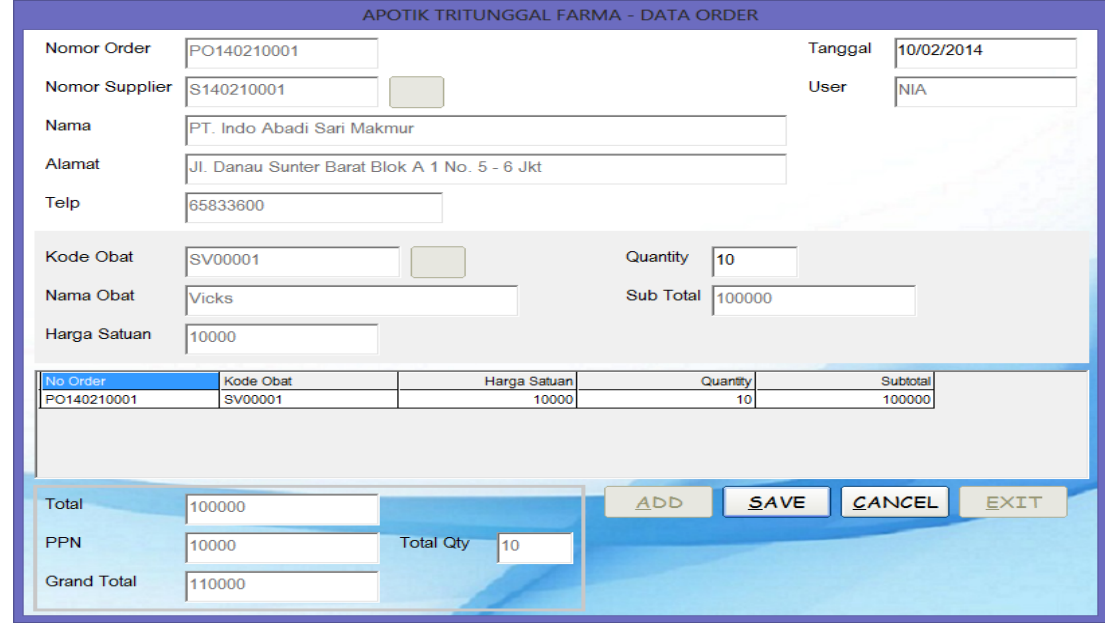

Gambar 15.

Tampilan Form Transaksi Order

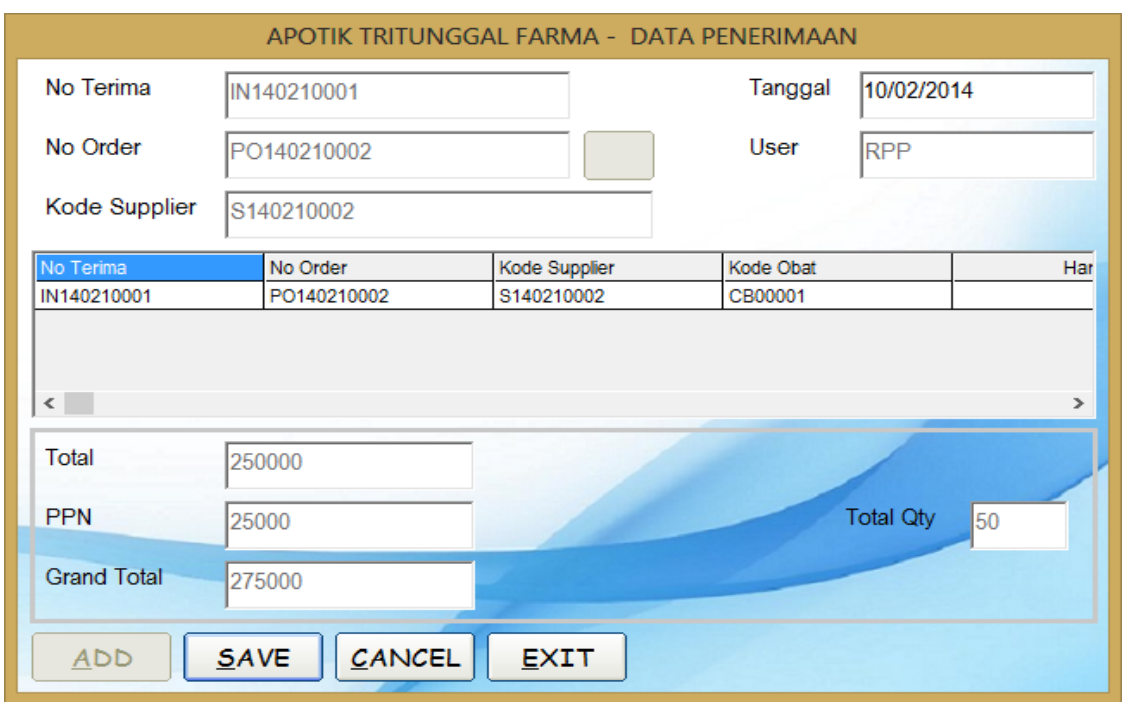

Gambar 16.

Tampilan Form Transaksi Penerimaan 


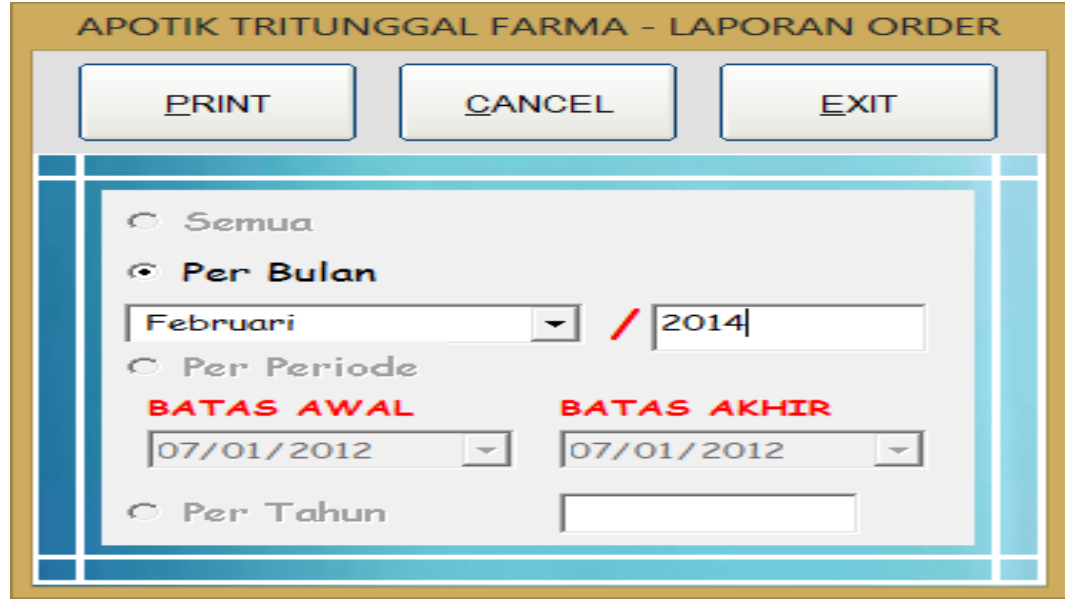

Gambar 17.

Tampilan Form Laporan Transaksi Order

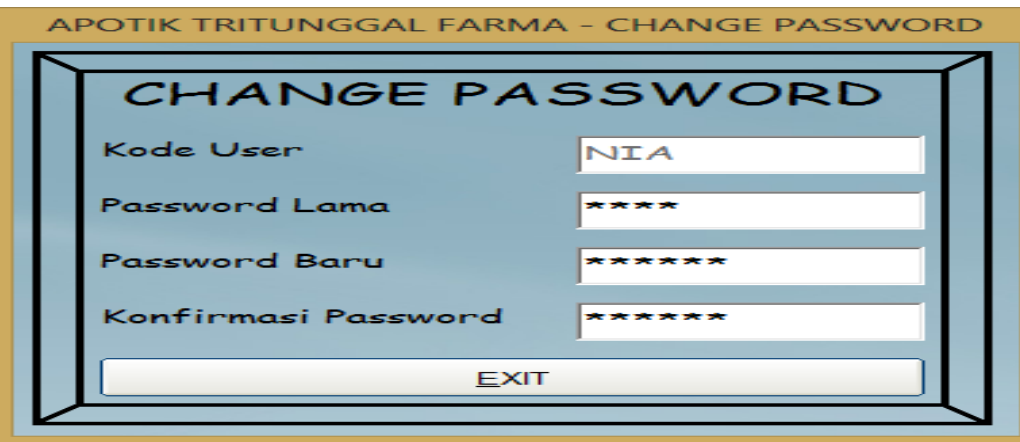

Gambar 18.

Tampilan Form Ganti Password

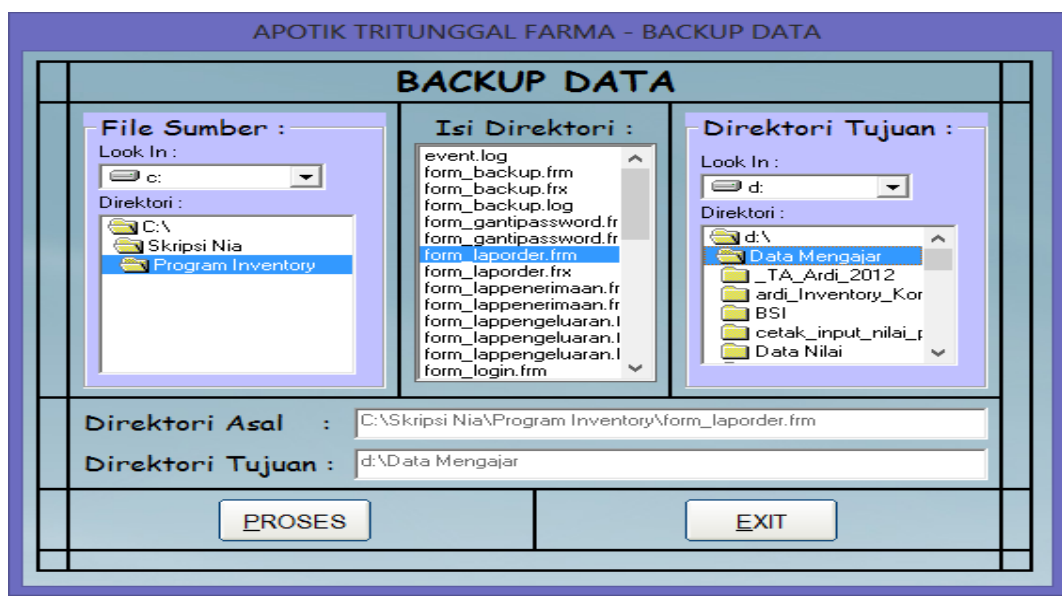

Gambar 19

Tampilan Form Backup Data

\section{KESIMPULAN DAN REKOMENDASI}

Kesimpulan yang dapat diambil setelah dilaksanakan penelitian adalah, bahwa adanya sistem inventory obat ini mempermudah admin dalam mengolah data transaksi sampai pembuatan laporan-laporan. Admin dalam hal ini bertugas untuk manajemen program inventory pada apotek ini. 
Rekomendasi yang dapat diberikan adalah, aplikasi visual basic yang telah dibuat hendaknya dioperasikan secara baik dan benar untuk mencapai tujuan yang diharapkan. Pemakai komputer (user) meningkatkan pengetahuan tentang hardware dan software secara seimbang dalam membantu kelancaran penerapan teknologi komputer serta paham tentang teknologi berbasis objek. Mengadakan sosialisasi program untuk admin atau kasir baru agar bisa mengoperasikan sistem dengan baik.

\section{REFERENSI}

A.S, Rosa dan M. Shalahuddin. 2011. Modul Pembelajaran Rekayasa Perangkat Lunak (Terstruktur Dan Berorientasi Objek). Bandung: Modula..

Astuti, Puspita Dwi. Perancangan Sistem Informasi Penjualan Obat Pada Apotek Jati Farma Arjosari. 2013. ISSN: 2302-1136. Universitas Surakarta: Fakultas Teknologi Informatika. Vol 2, No.1 Maret 2013.

Ladjamuddin, Al-Bahra Analisis Dan Desain Sistem Informasi. Yogyakarta: Graha Ilmu, 2013. pp. 70

Madcoms. 2011. Aplikasi Program Terintegrasi dengan Visual Basic 6.0. Yogyakarta: Andi Offset.

Mujiati, Hanik, Bambang Eka Purnama, Sukadi. 2013. Pembangunan Sistem Informasi Persediaan Obat Pada Apotek Arjowinangun. ISSN: 1979-9330. Universitas Surakarta: Fakultas Teknologi Informatika.

Mulyanto, Agus. 2009. Sistem Informasi KONSEP \& APLIKASI .Yogyakarta: Pustaka Belajar.

Rusdah. Analisa dan Rancangan Sistem Informasi Persediaan Obat: Studi Kasus Puskesmas Kecamatan Kebon Jeruk. 2011. ISSN: 2085-725X. Universitas Budi Luhur: Fakultas Teknologi Informasi. Vol 3, No.2 September 2011.

Widodo, Prabowo Pudjo dan Herlawati. 2011. Menggunakan UML. Bandung: Informatika 